\title{
FOCUSED TRAINING PROGRAMMES FOR SOLVING GROWTH PROBLEMS OF VERY SMALL BUSINESSES
}

\author{
S Perks \& EE Smith, Department of Business Management, Nelson Mandela Metropolitan University, \\ South Africa
}

\begin{abstract}
Purpose and objectives: The purpose of the study is to investigate the various types of focused training programmes that should be designed for eliminating or preventing small business growth problems. To help achieve this main objective, the following secondary goals are identified:

- To highlight the role and nature of entrepreneurial training.

- To identify possible focused training programmes for solving very small business problems.

- To determine how training programmes should be structured to target very small business growth problems.

- To explore which other method(s), besides training programmes could be uitilised for solving very small black business entrepreneurs' growth problems.

- To provide trainers with guidelines in designing focused training programmes for solving very small business problems.
\end{abstract}

Problem investigated: South African entrepreneurs have a poor skills record, which inhibits small business growth. The needs of a business changes as the business grows, resulting in growing pains for the very small business entrepreneur. Successful entrepreneurs are not necessarily academically inclined and often learn in a more dynamic, non-linear environment, therefore various specific focused training programmes need to be designed that can assist very small business entrepreneurs in eliminating or preventing small business growth problems.

Methodology: A qualitative study was done, in which an empirical survey was conducted by means of a series of in-depth interviews with ten very small black business entrepreneurs.

Findings: The empirical results identified seven types of training programmes focusing on financial management computer training, operations management, people management, marketing management, management and investment management. Other training programmes indicated were stress management, time management and security management. Within each of these types of training programmes specific focus areas were identified.

Value of the research: The value of the research lies in the fact that specific focus areas were identified within the training programmes. Other studies have attempted to identify training programmes but the content thereof was not necessarily linked to the problems that very small businesses experienced, especially when attempting to grow. Time-, staff- and financial constraints regarding training programmes can be overcome.

Conclusions: Training programmes should focus on specific training areas, be after hours and be well publicised. Computer training should preferably be on site on a one-to-one basis. Training programmes should suit the skills level of the very small business entrepreneurs and be broken up into smaller sessions to ensure understanding and meeting time constraints.

Key words and phrases: Growth problems; Training programmes; Training focus areas; Very small businesses.

\section{INTRODUCTION}

Entrepreneurial activity in South Africa is encouraged by government, who developed a legal framework, through the Small Business Amended Act (2003). Orford, Wood and Herrington (2004:10), however, state that entrepreneurial activity in South Africa is lagging behind other developing countries. According to the Canadian Youth Business Foundation (2006:1), entrepreneurs put everything on the line to start their enterprise - assuming risks and responsibility. Expertise is needed in different areas at different stages of their business. Orford et al., (2004:4) contend that it is necessary to: improve the quality and 
appropriateness of entrepreneurial education and training; introduce regulatory reform to assist small businesses both in terms of cost and administration; rethink methods of service delivery of support offered to small businesses and improving the financial and general management capacity of small business entrepreneurs. This article will highlight various types of focused training programmes that could be offered to overcome small business growth problems. Van der Walt (2004:1) concludes that entrepreneurs are the driving force behind small businesses and should be supported and assisted to enable them to fulfill their role in economic development. This notion is also held by the European Confederation of Young Entrepreneurs (2006:3), who argue that economic activity is the engine of growth for the small business entrepreneur.

The first aspect to be covered in this article is an outline of the research objectives and key concepts used in this article. Secondly, a theoretical overview is provided of training and the growth problems experienced by small business entrepreneurs. As no secondary information specific on very small businesses could be found, it was assumed that very small businesses will experience the same problems as small businesses. Thirdly, the research methodology followed in this study is provided. Lastly, the main research results, implications, recommendations and conclusions are highlighted.

\section{PROBLEM STATEMENT AND OBJECTIVES}

South Africa has a poor skills profile which inhibit productivity and growth, investment prospects and the sustainability of small businesses (Nel, Gerber, Van Dyk, Haasbroek, Schultz, Sono \& Werner, 2001:455). Karangu (2002:6) concurs that South African entrepreneurs are hindered more by the lack of business skills than money itself and that this lack of skills and capacity ultimately hinders the lack of access to capital needed to stimulate growth. Growth appears to be a natural and desirable consequence of being in business for a while. The needs of a business change as the business grows. These changes result in growing pains for the very small business entrepreneur. According to Nieman and Bennett (2002:63), a key challenge for small businesses is to overcome common limiting factors causing high failure rates and a lack of sustainability. Poor skills levels could be attributed to a lack of quality education; inappropriate public funded training and a low level of investment in training. However, it is necessary to build entrepreneurial activity beyond skill levels. According to Cope (2003:10), successful entrepreneurs are not necessarily academically inclined and often learn in a more dynamic, non-linear environment. It is for this reason that Orford et al. (2004:18) believes that targeted training could provide a faster and more effective means of developing the necessary competencies required by the entrepreneur.

The main objective of this article is to investigate the need for various types of focussed training programmes that can solve growth problems of very small business entrepreneurs. To help achieve this main objective, the following secondary goals are identified:

- To highlight the role and nature of entrepreneurial training

- To identify possible focused training programmes for solving very small business problems;

- To determine how training programmes should be structured to target very small business growth problems;

- To explore which other method(s), besides training programmes could be uitilised for solving very small black business entrepreneurs' growth problems;

- To provide trainers with guidelines in designing focused training programmes for solving very small business problems. 


\section{CONCEPT CLARIFICATION}

The following key concepts are defined as:

- Training according to Van Dyk, Nel, Loedolff and Haasbroek (2001:148) is basically a learning experience, focusing on specific skills and abilities needed to perform a job or is a "planned, systematic and organised process of providing employees with the specific knowledge and skills needed in their day-to-day work activities." (Nieman \& Bennett, 2002:265). Training is therefore an important management tool to develop the most important asset of an organisation.

- Growth is viewed according to the following perspectives of Nieman and Pretorius (2004:29): financial growth e.g. increases in turnover, costs and investment, profits and assets; strategic growth relating to changes in the way in which the organisation interacts with its environment by exploiting opportunities and assets to create sustainable competitive advantages; structural growth relating to changes in operational technology, in the environment impacting the business and structural requirements for implementing the strategy, and organisational growth relating to changes in the organisation's processes, culture and attitudes, the entrepreneur's role and leadership role as the business moves from "small" to "large".

- Very small businesses are described as owner-managed, having more than five but less than twenty employees and less than R2 million in assets, except in the agricultural sector and their business practices are more complex than micro businesses (Small Business Amended Act, 2003:6) or they have outgrown direct supervision by the entrepreneur (Department of Trade and Industry, 2003:14).

The following sections outline important theoretical aspects of training and solving growth problems of very small businesses.

\section{A THEORETICAL OVERVIEW OF TRAINING}

\section{The Nature of Entrepreneurial Training}

AllBusiness.com (2002:1) highlights the importance of training in developing small businesses. The Peterman Circle (2000:1) contends "the training of young entrepreneurs is a key to South Africa's economic future that can create their own wealth and business and jobs for others." Enterweb (2007:1) postulates that the cornerstone of a small business is entrepreneurship, finance, technology and the market - education and training is the cement, which holds them together. It appears that research on entrepreneurship education and training is sparse with the development of the literature in the area only in the past two decades. For entrepreneurship training and education to be effective, it must not only be through factual knowledge and limited skills acquired in the classroom, but also through other more practical interventions (The Foundation of Economic and Business Development, 2006:1). Thomson (2005:4) concurs by stating that there is a new trend and paradigm shift in entrepreneurial training that goes beyond campus classrooms and business plan competitions. The major challenge of entrepreneurship education and training is therefore the appropriateness of curricula and training programmes for learning in the outside world. Volery (2004:2) agrees that one of the pedagogic difficulties of teaching entrepreneurship originates from the complex and diverse range of entrepreneuropportunity situations. A variety of pedagogical tools can be used in entrepreneurship education and training, such as lectures, readings, testimonies, case analysis, journal writing and computer simulations. European Commission (2006:1) further dictates the fostering of entrepreneurial mindsets through education and learning by means of: better integration of programmes and activities into curricula; realising that the scope of entrepreneurship education is much wider than just training on how to start a business; including mentoring from people with business experience as a basic element off all entrepreneurship programmes and ensuring that it is not sufficient just to bring entrepreneurs into the classroom, but involve them directly in enterprise projects. O-Leary-Pickard (2006:1) concurs that in 
assessing the approach to training, the following aspects could assist in building a learning environment: create a learning culture in the business; appoint mentors and coaches in the business; build a sound infrastructure for training; ensure that the training vehicle fits the need; deliver just-in-time training and measure the results of training.

Selecting a training method

For a person working on a motorcar, some tools are more appropriate than others in performing certain functions. The same logic should apply when considering the many training methods available. O'LearyPickard (2006:1) states that "training is no longer limited to talking heads in classrooms, but the sheer diversity of vehicles for providing training provides entrepreneurs with a wide selection of alternatives." An important criterion in the selection of a training method must be the relative effectiveness of the method being considered for a particular training objective. Study of the literature reveals a variety of training methods (see for example Robbins \& DeCenzo, 2004; Van Dyk et al., 2001; WebAim, 2006 and ZeroMillion.com, 2006) but not all these methods might be suitable for training very small black business entrepreneurs. Various factors need to be taken into consideration when selecting a training method: training objectives; course content; target population; instructors; culture of the organisation; instructional space; facilities; equipment; materials; time and cost.

\section{Designing Training Programmes}

HighBeam Research (2007) postulates that entrepreneurship education and training devotes peripheral attention to the designing of training programmes. Often training programmes are designed that is not suitable for entrepreneurs. The Thomas Yaccato Group (2007) concurs that training programmes should be aimed at reaching the entrepreneur. According to Garavan and O'Cinneide (1994), the following are important cornerstones for designing training programmes for entrepreneurs:

- Learning by doing.

- Exploring wider concepts relating to a problem from a multi-disciplinary viewpoint.

- Developing more independence from external sources of information and expert advice (taking ownership for learning).

- Encouraging use of feelings, attitudes and values, placing more emphasis on experience-based learning).

- Providing opportunities for building networks and contacts in the outside world.

- Developing emotional responses when dealing with conflict situations.

The most important features of entrepreneurial focused education and training programmes according to Garavan and O'Cinneide (1994) are:

- "Gut feel" decision-making with limited information.

- Understanding the values of those transmitting and filtering information.

- Recognise the widely varied goals of theirs.

- Making decisions on the basis of judgment of trust and competence of people.

- Seeking to apply and adjust in practice to basic principles of society.

- Developing the most appropriate solution under pressure.

- Learning while and through during.

- Gleaning information from everywhere and weighing it.

- Evaluation by judgment of people and events through direct feedback. 
- Success in learning by solving problems and learning from failure.

Sauquet (2004) argues training programmes are often too broad in scope and not meeting specialised needs, entrepreneurs have low expertise in accessing training funds and entrepreneurs tend to work on many operational issues and do not plan their training needs. The following key designs aspects of entrepreneurial training programmes are outlined:

- More experience-based and progarmmes tailored to particular needs are required.

- Greater involvement of employee associations and chambers of commerce should be encouraged.

- New training programmes between universities and SME's should be promoted to create training programmes to foster specific competencies for innovation enhancement.

- Training programmes that combine multi-functional skills should be promoted.

- Design programmes that maximises network opportunities and promoting community training.

It should be clear that designing training programmes for small business entrepreneurs requires a different and unique approach and should include aspects that are specifically focused on the needs and operational situation of these entrepreneurs.

\section{SOLVING VERY SMALL BUSINESS GROWTH PROBLEMS}

Various authors (Alsbury, 2001:128; BusinessTown.com, 2003; Chadderton, 2001; Gibson, 2006; Henricks, 2006; Liraz, 2002:1; Perks, 2007:13-15 and Van Aardt, Van Aardt \& Bezuidenhout, 2000) identify the problems experienced in running or growing a small business. The problems identified by Perks (2007:13.15) were used as a framework for the summary in the table below on suggestions to solve small business problems.

Table 1:Suggested solutions for solving small business growth problems

\begin{tabular}{|c|c|c|}
\hline Problem & Solution to problem & Authors \\
\hline Financial & $\begin{array}{l}\text { - A balance between consuming and generating cash } \\
\text { - Adjusting initial estimated projections to definite } \\
\text { projections to secure finance } \\
\text { - Finding best sources of finance; negotiating good } \\
\text { credit periods with suppliers to improve cash flow } \\
\text { - Proof that business can deliver, be accountable and } \\
\text { flexible to be regarded by big busineses as credible }\end{array}$ & $\begin{array}{l}\text { Bolton \& Thomson, 2004:397; } \\
\text { Churchill \& Mullins, 2001:135; } \\
\text { Festervand \& Forrest, 1998:1; } \\
\text { Finlay, 2006:2; Masterminds on } \\
\text { Summit, 2002:1; Rodriquez, } \\
\text { 2006:1; Swart, 2003:151; Van } \\
\text { Aardt, Van Aardt \& } \\
\text { Bezuidenhout, 2000:156 }\end{array}$ \\
\hline $\begin{array}{l}\text { Marketing/ } \\
\text { Competitive } \\
\text { advantage }\end{array}$ & $\begin{array}{l}\text { - Matching product/service offering with external } \\
\text { environmental demands } \\
\text { - Targeting the right audience } \\
\text { - Getting the marketing message right } \\
\text { - Attract attention } \\
\text { - Differentiate business from competitors } \\
\text { - Exploit latest trends and technologies } \\
\text { - Conduct a competitive audit to reassess position }\end{array}$ & Gibson 2006; Fernandez 2006:2 \\
\hline Operational & $\begin{array}{l}\text { - Diversify product offerings } \\
\text { - Guard against expanding into a new market with a } \\
\text { new product or into an unknown market }\end{array}$ & $\begin{array}{l}\text { Ask Bob about managing growth, } \\
\text { 2001:1; Business Link, 2006:1; } \\
\text { Chadderton, 2001:2; Festervand }\end{array}$ \\
\hline
\end{tabular}




\begin{tabular}{|c|c|c|}
\hline & $\begin{array}{l}\text { - If market is small expand into additional markets } \\
\text { - Guard against over or quick expansion } \\
\text { - Maintain a consistent product quality and obtain } \\
\text { good raw materials and supplies }\end{array}$ & \& Forrest, 1998:2,3 \\
\hline $\begin{array}{l}\text { Human } \\
\text { resource }\end{array}$ & $\begin{array}{l}\text { - Find and keep a capable workforce that can cope } \\
\text { with daily business demands } \\
\text { - Staff must be able to think quickly, adapt well to } \\
\text { change and be prepared to work over-time } \\
\text { - Create a broad and deep management team }\end{array}$ & $\begin{array}{l}\text { BusinessTown.com, 2003; } \\
\text { Festervand \& Forrest, 1998:2; } \\
\text { Henricks, 2006; Rodriques, } \\
\text { 2006:2; }\end{array}$ \\
\hline Locational & $\begin{array}{l}\text { - Move to bigger premises to accommodate more } \\
\text { stock, new production line and staff } \\
\text { - Weigh up cost of renovations or higher lease fees } \\
\text { - Find a suitable location accessible for traffic flow, } \\
\text { cost effective, with parking and little competition }\end{array}$ & $\begin{array}{l}\text { Business Link, 2006:1; } \\
\text { BusinessTown.com, 2003; Marx, } \\
\text { Van Rooyen, Bosch \& Reynders, } \\
2004: 277\end{array}$ \\
\hline Management & $\begin{array}{l}\text { - Make time to do long-term planning, do not rely on } \\
\text { crisis management } \\
\text { - Avoid unplanned growth } \\
\text { - Balance business experience regarding business } \\
\text { functions } \\
\text { - Do retirement and succession planning }\end{array}$ & $\begin{array}{l}\text { BusinessTown.com, 2003; } \\
\text { Festervand \& Forrest, 1998:2; } \\
\text { Nieman, Hough \& } \\
\text { Nieuwenhuizen, 2003:234; } \\
\text { Robertson, 2005:2; Swart, } \\
\text { 2003:167 }\end{array}$ \\
\hline
\end{tabular}

This framework can be used as a guideline for identifying growth problems of very small businesses and possible solutions for solving these problems. It thus provides a comprehensive list of possible actions of entrepreneurs to ensure that small business growth problems are optimally solved.

The next section outlines the research methodology followed in this study.

\section{RESEARCH METHODOLOGY}

A qualitative research method was used, as it was concerned with the participants own written or spoken words, pertaining to their experience or perception (Brynard \& Hanekom, 2006:37). Furthermore, the qualitative methodology allows the researchers to know people personally, to see them as they are, and to experience their daily struggles when confronted with real-life situations. The qualitative research approach being used in this study is a combination of content analysis and grounded theory. Grounded theory aims to construct theory by producing concepts that fit the data, whereas content analysis refers to the gathering and analysis of textual data. Content analysis can, however, include quantitative and qualitative evaluations of text (Struwig \& Stead, 2001:14-15).

Information was acquired mainly from primary sources. Secondary literature sources were consulted beforehand to give an idea of appropriate questions to be asked, so as to encourage conversation during the interviews if the participant failed to address the issue, or to find out if the issue was irrelevant. As the study was qualitative and descriptive in nature, it was restricted to a maximum of ten very small black business entrepreneurs in the formal sector.

The database of a previous study done by Perks (2007) in the Nelson Mandela Metropolitan was used to conduct the empirical research as it was important to make sure as only very small businesses that have experienced growth would have be able to give meaningful responses to whether they could benefit from training programmes and what the content of these training programmes should be. The profile of the very small business entrepreneurs is as follows: Pipe fabrication (close corporation); Engineering of car parts (private company); Catering and café (sole proprietor); Interior decorator (sole proprietor); Manufacturing fans and stair cases (close corporation); Electrical, building construction and maintenance (close corporation); Marketing, advertising and design consultancy (close corporation); Traditional Xhosa 
wear and beauty products (close corporation); Leather products and traditional wear (close corporation) and Stationery (trust).

Only 10 very small business entrepreneurs were interviewed due to the length of the interviews and many observations, on site experiences and traveling. The sampling criteria as determined by the previous study done by Perks (2007) were: started as a micro entrepreneur and progressed to a very small business entrepreneur; being from the previously disadvantaged groups; that growth must have taken place, and having at least five permanent employees.

Data was collected over a six-month period. The interviews were mostly unstructured, non-directive and in-depth in nature. Informal discussions were initiated and conducted, allowing the participants freedom of expression. Probing questions were asked so as to explore the meaning of some actions and to ensure responses obtained were of high quality. The intention was to uncover the belief- and thinking structure of the participants. Extensive field notes were taken during the interviews. Observations during the interviews and on-site experiences were also noted. The interview schedule was divided into the following six sections: financial; computer-related; management; operations; marketing; human resources and locational. These sections were based on the types of problems experienced by very small business entrepreneurs as identified in a qualitative study done by Perks (2007). Each of these sections was covered in a separate interview so to focus the participants' thoughts and to reduce the analysis time. It also saves the time of participants as interviews took place on site during normal working hours. Many disruptions occurred during the interviews, but was viewed as positive as the participants could be observed in action. Some of their training needs were identified during these observations. During the interviews it was established whether participants regard training programmes as a possibility to prevent or solved very small business problems, and if so, what the specific content of these training programmes should be. Furthermore, if training programmes were not regarded as suitable, which alternative method could be utilised to overcome growth problems was explored.

Open, axial and selective coding was utilised (De Vos, Strydom, Fouché \& Delport, 2005:270). An initial coding scheme was developed from the first two cases when analysing the field notes. Notes were made of observations and critical incidents, to ensure consistency in the coding process. Codes were given to the main functions and further to the specific training needs within the functions so to establish the specific training programmes. These were then utilised for comparisons and modifications until all cases had been analysed. To make the data more manageable for presentation purposes the results were tabularised.

The synchronic reliability method was used in this study. Due to the fact that some of the participants actually know each other, they could supply some information about each other. The researcher could use this information to verify information received during the interviews. Institutions giving advice to the very small business entrepreneurs and supplying them with finance, verified the results, if the researcher doubted the validity of the information obtained during the interviews such as not using any additional finance. The triangulation method was used to ensure validity. The researcher personally communicated with the participants in informal conversations outside the places of work in order to verify information, if needed. Coding of data also ensured both reliability and validity. Reliability was further ensured through using an inter-coder reliability check. This means that the second author of this article reviewed the codes in order to improve the validity of interpretation of training programmes needed. In event of a disagreement, the help of academic-, business- and linguistic experts in that particular field were consulted.

The most important empirical research results of this study are highlighted in the following section. 


\section{RESULTS}

It must be noted that although there were only ten very small business cases, there were 13 participants. The detailed results of the life-story grid of these participants can be seen in an article of Perks (2007). A brief summary follows that outlines the most important issues in the life-story grid. All participants started the business without having employees, operating from home with little stock. Growth took place in terms of increase in turnover and increase in staff compliment from one person to at least five permanent staff members. It must be noted though that for the purpose of this study, businesses that made use of casual workers on a contract basis for three years, or more, have been regarded as permanent employees (for example electrical installation, building construction and maintenance). Most participants were in the 41 to 50 years age category, with almost all, having an above matric qualification. They have adequate working experience by having worked in a related field prior to starting the business or were previously self-employed. Most businesses were in existence between two to five years. The results of the training needs as indicated by participants are given in Table 2.

Table 2:Results of the training needs of participants

\begin{tabular}{|c|c|}
\hline Type of problems & Type of training programmes and focus areas \\
\hline \multicolumn{2}{|l|}{ FINANCIAL } \\
\hline Cash flow & Bookkeeping (Debtors accounts management; Inventory management) \\
\hline Access to finance & $\begin{array}{l}\text { Investment management (Asset needs analysis; Types of credit sources } \\
\text { and how to acquire long- and short-term capital; Managing growth; } \\
\text { Contract financing) }\end{array}$ \\
\hline Cost control & $\begin{array}{l}\text { Computer training (Information management; Creating a suppliers data } \\
\text { basis; Operations management (Operating JIT systems) }\end{array}$ \\
\hline Increase in overheads & Bookkeeping (Cost control) \\
\hline $\begin{array}{l}\text { Credibility at financial } \\
\text { institutions }\end{array}$ & $\begin{array}{l}\text { Investment management (Sales forecasting; Resource allocation) } \\
\text { Operations management (Capacity management; Resource allocation) }\end{array}$ \\
\hline Debt collection & $\begin{array}{l}\text { Bookkeeping (Debtors collection procedures) } \\
\text { Management (Problem solving techniques) }\end{array}$ \\
\hline Division not profitable & $\begin{array}{l}\text { Portfolio management (Managing central business units) } \\
\text { Management (How to enter foreign markets) }\end{array}$ \\
\hline \multicolumn{2}{|c|}{ COMPUTER-RELATED } \\
\hline E-mail facility & Computer training (Internet and e-mail usage) \\
\hline \multicolumn{2}{|l|}{ SELF MANAGEMENT } \\
\hline To relieve work stress & $\begin{array}{l}\text { Stress management } \\
\text { Time management }\end{array}$ \\
\hline \multicolumn{2}{|l|}{ OPERATIONS } \\
\hline Quality problems & $\begin{array}{l}\text { Operations management (Setting up a TQM system) } \\
\text { Computer training (Information management; Creating a supplier } \\
\text { database) }\end{array}$ \\
\hline Manual stocktaking & Computer training (Electronic inventory management) \\
\hline \multicolumn{2}{|l|}{ MARKETING } \\
\hline $\begin{array}{l}\text { Getting new or more } \\
\text { customers }\end{array}$ & $\begin{array}{l}\text { Marketing management (Networking for customers) } \\
\text { Management (How to enter foreign markets) }\end{array}$ \\
\hline Getting tenders & $\begin{array}{l}\text { Management (How to identify types of strategic partners) } \\
\text { Ethics (How to keep tender information secure) } \\
\text { Computer training (Information management; Finding information on } \\
\text { tenders available) }\end{array}$ \\
\hline
\end{tabular}




\begin{tabular}{|l|l|}
\hline Type of problems & Type of training programmes and focus areas \\
\hline $\begin{array}{l}\text { Expanding into another } \\
\text { target market }\end{array}$ & $\begin{array}{l}\text { Marketing management (How to advertise the business and products) } \\
\text { Customer relations management (How to get repeat customers) }\end{array}$ \\
\hline HUMAN RESOURCES & \\
\hline Insufficient staff & Operations management (Production scheduling) \\
\hline $\begin{array}{l}\text { Not enough working } \\
\text { hours in a day }\end{array}$ & People management (How to organise people and tasks) \\
\hline Delegation & People management (How to delegate) \\
\hline $\begin{array}{l}\text { Less Industrial } \\
\text { customer orders }\end{array}$ & $\begin{array}{l}\text { Management (Decline strategies) } \\
\text { Operations management (Lean management) }\end{array}$ \\
\hline Having skilled staff & $\begin{array}{l}\text { Marketing management (Networking for employees) } \\
\text { People management (Job rotation to get multi-skilled staff) }\end{array}$ \\
\hline Staff shortages & $\begin{array}{l}\text { Computer training (Information management; How to obtain learnership } \\
\text { students) } \\
\text { Management (Succession planning) }\end{array}$ \\
\hline LOCATIONAL & $\begin{array}{l}\text { Operations management (Locational analysis - Choosing a location) } \\
\text { Operations management (Facilities planning; Shop layout) }\end{array}$ \\
\hline Bigger premises & Security management (Protecting premises and other resources) \\
\hline Security in branch & Management (Product diversification; Choosing suitable product lines) \\
\hline $\begin{array}{l}\text { Refusal of Centre } \\
\text { management on } \\
\text { product line addition }\end{array}$ & \\
\hline
\end{tabular}

Although participants indicated attending training programmes in the above could be beneficial, time, financial and personnel constraints prevent them from attending such courses. Furthermore, they regard mentorship as a more ideal way of gaining the necessary experience to solve their business problems, but cannot afford the fees charged by mentors. They regard lack of access to additional finance, and to be regarded as credible, as issues that cannot in totality be addressed by training programmes. All participants indicated that they solve most of their problems through experimental learning (learning from their mistakes). They further indicate that they learn best if allowed to practice the task under supervision, in other words learn by doing.

This last section outlines the main implications and recommendations of this article with a few concluding remarks.

\section{IMPLICATIONS AND RECOMMENDATIONS}

Attention should be paid to the content of the programmes, cost and when these programmes will be offered due to participants' time, financial and personnel constraints. Participants also indicate that they learn best on a one-to-one basis and through learn by doing which implicated the need for mentorship.

As participants have time-, personnel- and financial constraints, trainers should take into consideration the following when offering training programmes:

- Training programmes could be broken up into smaller sessions targeting specific skills.

- Training programmes should be adapted to suit their financial knowledge level and experience.

- Training programmes that combine multi-functional skills should be promoted. 
- Information about training programmes should be widely published e.g. in free newspapers and on roadside posters.

- Computer training should rather be on a one-to-one basis on site, as participants could then learn by doing.

- Mentoring can also play a role but is too costly and is a longer process.

- Community specific training programmes in small groups, sponsored by government could be more beneficial than traditional teaching programmes.

- Greater involvement is needed from business associations and universities.

- The training programme must allow sufficient time for self-managed and individual-based learning.

- The content of training progarmmes should be a mixture of knowledge, skill competence and attitude domains of learning.

- Avoid stereotype ideas about training - lack of contextualization, cost and time lag before results appear as it can contribute to this stereotyping.

- Avoid too much focus on operational issues instead of focusing on training needs of entrepreneurs.

Figure 1 summarise the types and focus areas of the training programmes indicated by the participants as desirable, according to functional activities. 
Figure 1:Types of training programmes and focus areas

IYPE


Although participants indicated that they could solve their growth problems it was a lengthy and costly process as they learn from mistakes. The above types of training programmes with specific focus areas will show them how to deal with these particular growth issues and so save both time and money as they can hopefully then avoid learning from mistakes.

\section{CONCLUSIONS}

It can be concluded that all very small business growth problems can be addressed with training programmes, except access to additional finance and to be regarded as credible. The need for operations management and management training programmes were the most indicated, followed by investment management programmes. Computer training should preferable be on site on a one-to-one basis. Other programmes include self-management programmes such as stress and time management programmes. Better time management in itself can lead to better stress management. Security training for staff and how to protect resources was also an important issue due to high crime levels in South Africa. Most importantly, training programmes should amongst others, focus on specific training areas such as resource allocation; production scheduling; problem solving techniques; identifying types of strategic partners; product diversification; types of credit sources and managing growth.

To overcome time constraints, these training programmes should be offered after hours and be well publicised. Training programmes should suit the skills level of the very small business entrepreneurs and broken up into smaller sessions to ensure better understanding. As participants seem to favour training programmes on a one-to-one basis, it seems that mentorship can be an alternative training method.

The following extract appears to be appropriate with which to conclude this article:

"We do not understand how entrepreneurs learn, yet it is accepted that there is a learning experience from merely establishing a new enterprise. The learning process that is involved in business and enterprise development is poorly understood, yet programmes have been devised and interventions are made in business development. There is now a need for re-focussing research away from the emphasis on picking successful entrepreneurs or picking winners, to identifying key issues in the learning and developmental processes of entrepreneurship." (Deakins, 1996:21)

\section{REFERENCES}

AllBusiness.com. 2002. Entrepreneurship training for emerging SMEs in South Africa [Online] Available from: www.allbusiness.com/periodicals/article [Accessed: 15/03/2006].

Alsbury A. 2001. Quick answers to small business questions. London: Prentice Hall.

Armstrong S. 2003. Mentoring programme standard for designing a mentoring programme that works [Online] Available from: www.workinfo.com [Accessed: 19/04/2006].

Ask Bob about managing growth. 2001. Managing a small business [Online] Available from: www.businesstown.com/managing/growth-aq.asp [Accessed: 21/04/2006].

Bolton B \& Thompson J. 2004. Entrepreneurs: Talent, temperament, technique. Oxford: Butterworth \& Heinemann.

Brynard PA \& Hanekom SX. 2006. Introduction to research in management related fields. Pretoria: Van Schaik Publishers. 
Business Link. 2006. Assess your options for growth: The practicalities of growth [Online] Available from: www.businesslink.gov.uk/bdotg/action/detail [Accessed: 26/04/2006].

BusinessTown.com. 2003. Managing a small business: Managing growth [Online] Available from: www.BusinessTown.com/managing/growth-manage.asp [Accessed: 31/01/2007].

Canadian Youth Business Foundation. 2006. Mentoring the next generation of entrepreneurs [Online] Available from: www.cybf.ca/downloads [Accessed: 15/03/2006].

Chadderton L. 2001. My biggest mistakes: Analysing the archives [Online] Available from: www.inc.com/guide/itme/0,7462, AGDI [Accessed: 15/03/2006].

Churchill NC \& Mullins JW. 2001. How fast can your company afford to grow? Harvard Business Review, 79(5).

Cohen N. 1999. Effective mentoring. Massachusetts: HRD Press.

Cope J. 2003. Towards a dynamic learning perspective of entrepreneurship [Online] Available from: www.lum.ac.uk/publications [Accessed: 19/04/2006].

Deakins D. 1996. Entrepreneurship and small business firms. London: McGraw-Hill.

De Vos AS, Strydom H, Fouché CB \& Delport CSL. 2005. Research at grass roots. Pretoria: Van Schaik Publishers.

Enterweb. 2007. Education and training [Online] Available from: www.enterweb.org/edutrain [Accessed: 31/01/2007].

European Commission. 2006. Conference: Entrepreneurship education in Europe - Fostering entrepreneurial mindsets through education and learning. Oslo: 26-27 October 2006.

European Confederation of Young Entrepreneurs. 2006. Entrepreneurship - The winds of change [Online] Available from: www.unece.org/indust/sme [Accessed: 15/03/2006].

Fernandez A. 2006. Marketing savvy design [Online] Available from: www.rebootyourbottomline.com. [Accessed: 26/04/2006].

Festervand TA \& Forrest JE. 1998. Small business failures: A framework for analysis [Online] Available from: www.sbaer.uca.edu/research/sbida [Accessed: 21/04/2006].

Finlay B. 2006. 7 Critical business financing mistakes [Online] Available from: www.buzzle.com/editorials [Accessed: 25/04/2006].

Garavan TN \& O Cinneide B. 1994. Entrepreneurship education and training programmes: A review and evaluation (Part 2). Journal of European Industrial Training, 18(11):13-21.

Gibson SG. 2006. Determining the common problems of early growth small businesses in Eastern North Carolina [Online] Available from: www.AllBusiness.com/management/1190108-1.html [Accessed: 31/01/2007].

HighBeam Research. 2007. Designing management education and training programs for service firm entrepreneurs [Online] Available from: www.findarticles.com/p/articles/mi [Accessed: 9/10/2007]. 
Henricks M. 2006. Growing in the fast lane [Online] Available from:

www.entrepreneur.com/entrepreneur/2005april/76642.html [Accessed: 31/01/2007].

Karangu DR. 2002. Access to finance [Online] Available from: www.apdf.co.za/conferencepapers [Accessed: 19/04/2006].

Liraz M. 2002. Are you making any of these 10 deadly small biz mistakes? [Online] Available from: www.bizmove.com/msb-new/top10new.sht [Accessed: 15/03/2006].

Marx S, Van Rooyen DC, Bosch JK \& Reynders HJJ. 2004. Business Management. $2^{\text {nd }}$ Ed. Pretoria: Van Schaik Publishers.

Masterminds on Summit. 2002. Enterprise: Confidence and flair vital to the entrepreneurial spirit [Online] Available from: www:businessday.co.za...ntent/direct [Accessed: 19/04/2006].

Nel PS, Gerber PD, Van Dyk PS, Haasbroek GD, Schultz HB, Sono T \& Werner A. 2001. Human Resources Management. Cape Town: Oxford University Press.

Nieman G \& Bennett A. 2002. Business management: A value chain approach. Pretoria: Van Schaik Publishers.

Nieman G, Hough J \& Nieuwenhuizen C. 2003. Entrepreneurship: A South African perspective. Paarl: Van Schaik Publishers.

Nieman G \& Pretorius M. 2004. Managing growth: A guide for entrepreneurs. Cape Town: Juta Publishers.

O'Leary-Pickard M. 2006. Training for small business: A learning organization [Online] Available from: www.bdc.ca/en/about/events [Accessed: 5/04/2006].

Orford J, Wood E \& Herrington M. 2004. Global Entrepreneurship Monitor: South African Report. Cape Town: UCT Graduate School of Business.

Perks S. 2007. Problems and problemsolving techniques of very small businesses. Conference proceedings $1^{\text {st }}$ International Business Conference, 29-31 August, Mauritius.

Robbins SP \& DeCenzo DA. 2004. Supervision today. New Jersey: Pearson Education.

Robertson D. 2005. Advice on succession planning for small business owners [Online] Available from: www.bytestart.co.uk/content/legal/35-2/advice-on-succession-plan.shtml [Accessed: 26/04/2006].

Rodriques G. 2006. 10 Ways small businesses can compete with the big boys [Online] Available from: www.powerhomebiz.com/vol113/compete.htm [Accessed: 26/04/2006].

Sauquet A. 2007. New perspectives for learning: Small business training and competitiveness [Online] Available from: www.pjb.co.uk/npl [Accessed: 9/10/2007].

Small Business Amended Act. 2003. Small Business Act No.26 [Online] Available from: www.info.gov.za/gazette/acts/2003/aza-04pdf [Accessed: 31/01/2007].

Struwig FW \& Stead GB. 2001. Planning, designing and reporting research. Cape Town: Maskew Miller Longman Pty Ltd. 
Swart N. 2003. Manage your money: Basic financial life skills for South Africans. Pretoria: Van Schaik Publishers.

The Foundation of Economic and Business Development. 2006. [Online] Available from: www.iconnect-online.org [Accessed: 21/02/2006].

The Peterman Circle. 2000. Training of young entrepreneurs - The role of schools [Online] Available from: www.peterman.co.za [Accessed: 3/02/2004].

The Thomas Yaccato Group. 2007. Sales, marketing and communication training programs: Reaching the entrepreneur [Online] Available from: www.thethomasyaccatogroup.ca/training [Accessed: 9/10/2007].

Thomson LA. 2005. Funding and mentoring young entrepreneurs [Online] Available from: www.conectutah.co./article [Accessed: 15/03/2006].

Van Aardt I, Van Aardt C \& Bezuidenhoudt S. 2000. Entrepreneurship and new venture management. $2^{\text {nd }}$ ed. Cape Town: Oxford University Press.

Van der Walt L. 2004. Cooperatives and entrepreneurs: A partnership for job creation and economic development. North-West University: Potchefstroom Business School.

Van Dyk PS, Nel PS, Loedolff P \& Haasbroek GD. 2001. Training management: A multi-disciplinary approach to human resources development in Southern Africa. Cape Town: Oxford University Press.

Volery T. 2004. Entrepreneurship and enterprise education in Europe: What must be learnt and what can be taught. EntreNews, 2:1-4.

WebAim. 2006. Engaging learners with various training methods [Online] Available from: www.webaim.org/training [Accessed: 5/04/2006].

ZeroMillion.com. 2006. Employee training and development [Online] Available from: www.zeromillion.com/business/personnel/employee-training. [Accessed: 5/04/2006]. 